\title{
Police Training Practices in Ghana: An Empirical Analysis
}

\author{
${ }^{1}$ Ronald Osei Mensah $\quad{ }^{2}$ Daniel Ennin \\ ${ }^{1}$ M.Phil. Graduate, Department of Sociology and Anthropology, University of Cape Coast \\ ${ }^{2}$ M.Phil. Graduate, Department of Sociology, University of Ghana \\ Abstract \\ This study was carried out to do an empirical analysis of police training practices in the Ghana Police Service \\ taking the National Police Training School, Accra and the Winneba Police Command and Staff College, \\ Winneba into perspective. The study aimed at finding out the demographic characteristics of police officers and \\ trainees, the academic qualification (s) of police officers, the criteria for police recruitment, the criteria for \\ training of police officers, the duration of the training programme and the motivational factors for one to pursue \\ career in law enforcement. The study employed the mixed methods by using both quantitative and qualitative \\ approaches in getting the relevant data to satisfy the purpose and objectives of the study. Sampling methods used \\ were purposive and simple random sampling methods. In-depth interviews were also conducted to elicit \\ qualitative data. The study revealed that males are more than females in the Ghana Police Service. In addition, \\ the study revealed that the Akan and Ewe dominated the Ghana Police. Notwithstanding, most of these police \\ trainees were unmarried. The study further revealed that majority of the respondents were Senior High School \\ Certificate holders and they did not have any relatives as police officers before they entered into police service. \\ This implies that Senior High School graduates are employed more than any other category in the Ghana Police \\ Service. The study further shown that the police service has a general and standard criterion for recruiting \\ personnel into the service. The Ghana Police Service follows these criteria religiously before a prospective \\ applicant is recruited into the service. It is concluded that the criteria for police training takes the form of \\ Physical Training (PT), drill, classroom work, weapon training, parade, defensive tactics training, oral training, \\ firearms range, scenario training, driving skills, equipment training, mental training, visiting, preps, and an \\ examination. It can be concluded that majority of the respondents were of the view that the motivational factor \\ for entering into the police service was because of the salary structure and also getting the opportunity to help \\ people in their community.
}

Keywords: Training, Training Practices, Trainees, Trainers, Recruit, Police Officer

DOI: $10.7176 / \mathrm{IKM} / 9-3-06$

Publication date:March $31^{\text {st }} 2019$

\subsection{Introduction}

There are some deficiencies that tend to constrain police training. Some of these deficiencies are lack of modern training facilities, inadequate logistics, inadequate instructors, low level of technology among others. These can be referred to as challenges facing police training academies. These deficiencies tend to hinder the success of the training given to police trainees thereby preventing the required results not to be achieved at an appreciable level (Mensah, 2019).

Traditional training focused on physical activities, such as firearms training, physical training, defensive tactics and driving. Traditional training also included some knowledge areas such as law, arrest procedures, traffic enforcement and officer safety. Areas that were neglected include communications, diversity, problem solving, and police-community relations (Dantzker, Lurigio, Hartnett, \& Houmes, 1995; Trojanowicz \& Belknap, 1986 as cited in Mensah, 2017). Police' Service-specific knowledge and skills need to be formally learned in police training institutions and work environment to bring the expected results (Mensah, 2017). This is because those institutions exist to provide the relevant and specific knowledge as well as the right orientation for work in the Service.

From the discussion above, training generally means investing resources, be it time, money, skills and knowledge into trainees in order to perform a particular task or a job. Most authors are of the view that training is very important to the police service because it has to perform certain roles which can only be achieved through special and effective training. One may ask, what goes into effective training? This is when trainees are being trained properly with all the needed resources; achieve expected results on time and are being monitored. With all these variables, training is said to be effective (Mensah, 2018).

Despite the fact that some studies have been done on police training practices, previous research has not been able to explore critically into police demographics and the scope of training employed by police trainers in the training academies in order to really assess the training practices of these officers. As a result, it has created gaps in the work delivery of police officers and the Ghana Police Service as a whole. On the other hand, when these gaps are resolved, the expected results would be ascertained. This paper therefore aims to do an empirical analysis of police training practices in Ghana looking at the demographic characteristics of police officers, their academic qualification (s), the criteria for recruitment, the criteria for training police officers, the duration of 
their training programme and the motivational factors for one to pursue a career in law enforcement (Mensah, 2017)

\subsection{Research Questions}

1. What are the demographic characteristics of police personnel?

2. What is the academic qualification (s) of police respondents?

3. What are the criteria for recruitment into the police service?

4. What are the criteria for training police officers?

5. What is the duration for police training programme?

6. What are the motivational factors for one to pursue career in law enforcement?

1.2 Significance of the paper

This study is being conducted with the prime aim of providing an empirical data analysis of police training practices in Ghana. The study objectively looked at the demographic characteristics of police personnel in Ghana, the academic qualification (s) of police personnel in Ghana, the criteria for recruitment, the criteria for training police officers, the duration of the training programme and the motivational factors for one to pursue a career in law enforcement. The outcome of this study will confirm to what we know already and also add to existing knowledge of police training. The study will serve as a source of empirical literature for anyone who wants to undertake a study in police training or any other related area.

\subsection{Methodology \\ 2.1 Research Design}

Ogula (2005) describes research design as a plan, structure and strategy of investigation to obtain answers to research questions and control variance. Kumekpor (2002) also asserted that the end results of scientific investigation is useful only to the extent that the most efficient techniques and procedures are adopted in the planning and execution of field operations as well as the data collected. The descriptive research design was chosen because it offered the researcher the opportunity to use varied instruments such as questionnaires and interview guide to elicit information from the police trainees, trainers and police officers. It also provided a detailed account of the demographic characteristics of police officers, their qualifications, the criteria for training, the duration of the training programme and the motivation factors to pursue a career in law enforcement.

The researcher adopted mixed method approach by administering questionnaires out to his respondents to be filled and conducting some in-depth interviews. The Mixed method (quantitative and qualitative) approach was adopted to give a clearer description and understanding of the issues being discussed.

\subsection{Study Area}

The study seeks to provide an empirical data analysis on police training practices in the Ghana Police Service (GPS) at the National Police Training School (NPTS), Accra and the Winneba Police Command and Staff College (WPCSC) at Winneba.

\subsection{Population}

Castillo (2009) states that, a research population is generally a large collection of individuals or objects that is the main focus of a scientific query. The ages of the population range from 20-60. The population comprises of both males and females with basic education and with some higher education. Some of these people are with secondary school certificate, diploma, professional certificate, first degree and others with master's degree. These people have various rankings like constable, corporal, sergeant, inspectors, chief inspectors, assistant superintendent, deputy superintendent, superintendent and chief superintendent. The estimated size of the population is 188 comprising of trainees, trainers and officers who have undergone the training programme already.

The target population of the study was the Commanding officer of the National Police Training School (NPTS), Trainers/instructors at the training academy, Officers who have already undergone through the training process and trainees at the training academy.

\subsection{Sampling Procedure}

\subsubsection{Sample size determination of Trainees}

A sample is a finite part of a statistical population whose properties are studied to gain information about the whole (Webster, 1985). Slovin's formula was adopted to set limit for the number of trainees to be selected from the National Police Training School. The Slovin's formula is

$n=\frac{N}{1+N e^{2}}$ 
Where: $\mathrm{n}=$ the sample size, $\mathrm{N}=$ sample frame or the target population and $\mathrm{e}=$ Degree of freedom with a margin error of 0.05 (confidence level of $95 \%$ ). If the total number of trainees is 153 and it is substituted into the formula, mathematically the number of trainees to be interviewed would be calculate as $n=153 / 1+153(0.05)^{2}=$ 110.67 to the nearest decimal is 111 . Therefore the number of respondents to be selected as trainees from the National Police training academy is 111 whilst the respondents to be selected as trainees from the Winneba Police Command and Staff College are 33. This is because the researchers had 33 as the whole population for senior officers at the Winneba Police Command and Staff College (WPCSC) and were interviewed by administering questionnaires to them through the simple random sampling technique.

\subsubsection{Total sampling size for the study}

Total number of people who participated in the study is captured in table 1 below:

Table 1: Sample Technique and Size for the Study

\begin{tabular}{lll}
\hline $\begin{array}{l}\text { Respondents for quantitative } \\
\text { data }\end{array}$ & Sampling technique & Number \\
\hline $\begin{array}{l}\text { Trainers/ instructors } \\
\text { (NPTS/WPCSC) }\end{array}$ & Simple Random & 20 \\
$\begin{array}{l}\text { Trainees (NPTS) } \\
\text { Trainees (WPCSC) }\end{array}$ & Simple Random & 111 \\
$\begin{array}{l}\text { Officers who have undergone } \\
\text { the training programme }\end{array}$ & Simple Random & 33 \\
(NPTS/WPCSC) & Simple Random & 20 \\
\hline Participants for qualitative & & \\
data & & \\
\hline $\begin{array}{l}\text { Commanding Officer (NPTS) } \\
\text { Administrators (NPTS/WPCSC) }\end{array}$ & Purposive & Purposive \\
Total & & 3 \\
\hline
\end{tabular}

\subsection{Data Collection Instruments}

Instruments for data collection were both quantitative and qualitative. Quantitative data collection instruments were questionnaires whereas qualitative instrument was an interview guide.

\subsection{Sources of Data}

Sources of data for the study were both primary and secondary. Secondary sources were books related to the area, research journals and any other source(s) which was relevant to the purpose of the study. The research unit of the Ghana Police Service (GPS), Headquarters, Accra was consulted for some information pertaining to police training practices.

Primary sources of information were elicited through structured interviews with some trainees at the Winneba Police Command and Staff College and the National Police Training School, trainers or instructors at the college and some officers who have undergone the training programme were interviewed in order to know their experience. The Commanding officer of the National Police Training School (NPTS) was also interviewed to find out the academic qualification (s) of police officers and trainees, the criteria for recruitment and some motivational factors in the police work.

\subsection{Validity and reliability of instrument}

Validity and reliability play an important role in determining the quality of an instrument designed for a research or study. According to Taale and Ngman-Wara (2015), validity refers to the appropriateness of the evaluation instrument for a given group of individuals and not to the instrument itself. In other words, validity refers to the degree to which a research instrument measures what it is proposed for. Reliability on the other hand as defined by Taale and Ngman-Wara (2015) is the consistency with which a test measures whatever it measures from one measurement to another, over and over again.

\subsection{Data Processing and Analysis}

The data collected was edited, coded and analyzed. The quantitative data that was generated by the study was processed and analyzed using Statistical Package for the Social Science (SPSS) computer software package (version 20.0 for Microsoft windows). Findings from the analysis were presented in contingency tables with summary statistics. 
On the other hand, qualitative data was analyzed by transcribing recorded audio discussions from various respondents before transferring it onto the computer.

\subsection{Ethical Considerations}

Since the police institution is a sensitive one, permission and approval was first sought from the commanding officer at the National Police Training School, Accra and the Commandant at the Winneba Police Command and Staff College, Winneba. Individuals sampled for this study were subjected to voluntary participation and they were guaranteed confidentiality and anonymity. In order to ensure confidentiality of the information obtained from the respondents, their identity was kept anonymous. They were assured that whatever information they gave would be used only for academic purposes and would be protected

\subsection{Results and Discussion}

\subsection{Research Question One: What are the demographic characteristics of police personnel?}

Table 2 discusses the demographic characteristics of respondents such as sex, ethnic background and marital status. This is very important because it helps the researcher to know the sex segregation of respondents in this study and in the police profession.

Table 2: Sex, Ethnic Background and Marital Status of respondents

\begin{tabular}{|c|c|c|c|c|c|}
\hline \multirow{3}{*}{ Characteristics } & \multirow{2}{*}{\multicolumn{2}{|c|}{$\begin{array}{l}\text { Police } \\
\text { Officers }\end{array}$}} & \multirow{2}{*}{$\begin{array}{l}\text { Winneba } \\
\text { Trainees } \\
\text { (Senior } \\
\text { officers) }\end{array}$} & \multirow{2}{*}{$\begin{array}{l}\text { Accra } \\
\text { Trainees } \\
\text { (recruits) }\end{array}$} & \multirow{2}{*}{ Trainers } \\
\hline & & & & & \\
\hline & \multicolumn{2}{|c|}{$\mathrm{F}(\%)$} & $\mathrm{F}(\%)$ & $\mathrm{F}(\%)$ & $\mathrm{F}(\%)$ \\
\hline \multicolumn{6}{|l|}{ Sex } \\
\hline Male & \multicolumn{2}{|c|}{$10(50.0)$} & $21(63.6)$ & $85(76.6)$ & $16(80.0)$ \\
\hline Female & \multicolumn{2}{|c|}{$10(50.0)$} & $12(36.4)$ & $26(23.4)$ & $4(20.0)$ \\
\hline \multicolumn{6}{|l|}{$\begin{array}{l}\text { Ethnic } \\
\text { Background }\end{array}$} \\
\hline Mole Dagbani & \multicolumn{2}{|c|}{$4(20.0)$} & $8(24)$ & $4(3.6)$ & 0 \\
\hline Akan & \multicolumn{2}{|c|}{$5(25.0)$} & $17(52)$ & $79(71.2)$ & $4(20.0)$ \\
\hline Ewe & \multicolumn{2}{|c|}{$11(55.0)$} & $8(24)$ & $20(18.0)$ & $15(75.0)$ \\
\hline Ga Adangbe & \multicolumn{2}{|l|}{0} & 0 & $8(7.2)$ & $1(5.0)$ \\
\hline \multicolumn{6}{|l|}{ Marital Status } \\
\hline Married & \multicolumn{2}{|c|}{$12(60.0)$} & $32(96.9)$ & $21(18.9)$ & $18(90.0)$ \\
\hline $\begin{array}{l}\text { Unmarried } \\
\text { Age }\end{array}$ & \multicolumn{2}{|c|}{$8(40.0)$} & $1(3.0)$ & $90(81.1)$ & $2(10.0)$ \\
\hline$(15-19)$ & & 0 & 0 & 0 & 0 \\
\hline$(20-24)$ & & $2(10)$ & 0 & $9(8.1)$ & 0 \\
\hline (25 and & bove) & $18(90)$ & $33(100)$ & $102(91.9)$ & $20(100)$ \\
\hline
\end{tabular}

Out of the twenty (20) police officers who have undergone the training programme, $50 \%$ were males while $50 \%$ were females. Out of the 33 trainees from Winneba, $64 \%$ were males and $36 \%$ were females. However, $77 \%$ male trainees as well as $23 \%$ female trainees responded to the questionnaires at the National Police Training School, Accra. The results also revealed that $80 \%$ of the trainers were males while $20 \%$ were 
females. It can be deduced from the foregoing analysis that the majority of the respondents were males which implies that the profession in question is a male dominated one. This is because from the inception of the police force in the Gold Coast, men numbering one-hundred and twenty-nine (129) were the first police force to be recruited known as the Gold Coast Corps and later the Royal Corps (Ghana Police Service, 2009).

This has made the police force to be a male dominated one and this has transpired in many institutions whereby males dominate. Sociologically, it can be said that males are mostly found in the security services and that has called for gender inequality in the security service. This has given men some position in society that they are much capable of being in the security service than females. All these instances have perpetuated till now which has made our society a male dominated one hence the Ghana Police Service.

With respondents' ethnic background, Police officers claimed 55\% were Ewes, 25\% were Akans whilst $20 \%$ were Mole-Dagbani. Also, trainees from the Winneba Police Training School claimed that 52\% were Akan, whereas 24\% each represented Mole and Ewe respectively. Furthermore, trainees from the National Police Training School (NPTS) were of the view that $71.2 \%$ were Akan whereas $18 \%$ were Ewes. Trainers who were interviewed subscribed to the assertion that $75 \%$ of the police men and women were Ewe whereas $20 \%$ were Akan. The above discussion shows that majority of the respondents were Akan. This implies that Akan dominated in the Ghana Police Service than any other ethnic. This confirms the 2010 National Population and Housing Census report that the Akan ethnic group constitutes the larger population in Ghana.

With the marital status of police officers $60 \%$ of police officers were married while $40 \%$ were unmarried. 96.9\% of the Winneba trainees in the Ghana Police Service were married, 3\% were unmarried. Furthermore, $19 \%$ of the trainees in Accra were married whilst $81.1 \%$ were unmarried. The results also reveal that $90 \%$ of the trainers were married whereas $10 \%$ were unmarried. The majority of the respondents who were police officers, trainees from Winneba and trainers were married. However, the majority of police trainees in Accra who constituted a greater population in the study were unmarried. This can further imply that most personnel in the Ghana Police Service especially recruits are not married because young people (recruits) who fall within the age bracket of [18-25 years] are mostly enlisted and they need to serve for 18 months' probation in the service before they get married.

In reference to age, $10 \%$ of police officers fell within (20-24) whereas $90 \%$ fell within the age bracket of ( 25 and above). Trainees from the Winneba Police Command known as senior officers all fell within the age bracket of (25 and above) representing 100\%. Majority of the trainees or recruits from the NPTS fell within the age bracket of (25 and above) representing $91.9 \%$ whereas $8.1 \%$ fell within the age bracket of (20-24). Lastly trainers from both schools all fell within the age group of (25 and above) representing $100 \%$. This confirms Pokoo-Aikins, 2009 assertion that all recruits must be between eighteen and twenty-five years of age and graduates between twenty-six and thirty-five years. This implies that most personnel from the Ghana police service be it trainees, trainers and police officers fell within the age group of ( 25 and above) hence adults.

\subsection{Research Question 2: What is the academic qualification (s) of police respondents?}

The qualification of workers in every institution is very important. Research indicates that adequate performance in all areas of policing requires specially selected and specially trained police personnel with some level of education (Cox, 1996). With the qualification of respondents, it tells how well an employee of an organisation or institution can handle a particular situation and the class suitable for that employee. In relation to this study, qualification of respondents is very important in selecting and recruiting of police officers since it brings about competency and quality delivery of duties in the police service. The data provided gives a clear cut of the relationship between the depth of knowledge and the result practice. 


\begin{tabular}{lllll}
\multicolumn{1}{l}{ Table 3: Qualification of Respondents } & \multicolumn{3}{l}{} \\
\hline Variables & $\begin{array}{l}\text { Police } \\
\text { officers }\end{array}$ & $\begin{array}{l}\text { Winneba } \\
\text { Trainees } \\
\text { (Senior } \\
\text { officers) } \\
\text { F (\%) }\end{array}$ & $\begin{array}{l}\text { Accra Trainees } \\
\text { (recruits) }\end{array}$ & Trainers \\
& F (\%) & & F (\%) \\
\hline $\begin{array}{l}\text { Senior High School } \\
\text { Certificate }\end{array}$ & $11(55.0)$ & 0 & $87(78.4)$ & 0 \\
$\begin{array}{l}\text { Technical School } \\
\begin{array}{l}\text { Certificate } \\
\text { Diploma Certificate }\end{array}\end{array}$ & $5(25.0)$ & $3(9.0)$ & $14(12.6)$ & $3(15.0)$ \\
Bachelor's Degree & $2(10.0)$ & $5(15.2)$ & $7(6.3)$ & $1(5.0)$ \\
\hline
\end{tabular}

Out of the 20 police officers, $55 \%$ had Senior High School Certificate, $25 \%$ had Technical School Certificate, whilst 10\% each had Diploma and Bachelor's degree certificate. Furthermore, out of the 33 police trainees at Winneba, 75.8\% had Bachelor's degree certificate whereas $9 \%$ had technical school certificate.

With the trainees from the NPTS $78.4 \%$ had Senior High School Certificate, $12.6 \%$ had Technical School Certificate whereas $6.3 \%$ had Diploma certificate. Again, the results show that $80 \%$ of police trainers had bachelor's degree certificate whereas $5 \%$ had diploma certificate.

Using Parson's AGIL theory, 1951, Adaptation best fits here because all the resources including the various qualifications of police officers help the police institution to meet its standards. From the above discussion, it can be concluded that majority of the respondents at the National Police Training School in Accra are Senior High School Certificate holders whereas majority of the trainees at the Winneba Police Command are Bachelor Degree holders.

Furthermore, it is realized from the table that most trainers at the police training schools have Bachelor's Degree Certificate. From the literature in related studies conducted by the main author, it was also realized that most instructors are lecturing based on their experience and not their qualification. This has its own adverse effects on the depth of knowledge and the expected results. It can therefore be concluded that there are some basic social standards set in every organisation or institution. This implies that most of police personnel at the National Police Training School are Senior High School Certificate holders who are known as recruits.

\subsection{Research Question 3: What are the criteria for recruitment into the police service? 3.3. 1 Criteria for recruitment into the Ghana Police Service (GPS) for Recruits}

The responses given indicate that the Ghana Police Service follows a systematic procedure and a standardized process in their recruitment. From the results obtained from the field and the research department of the GPS this procedure is applied nationwide.

The first criterion is that a prospective applicant should be Ghanaian by birth. Also, the applicant must have attained 18 years and not more than 25 years. The applicant must be at least 5 feet 8 inches [173cm] tall for males, and 5 feet 4 inches [163cm] for females. The applicants must be physically fit and must be of good character with no criminal record. With academic qualification, the applicants must possess a minimum qualification of Six [6] credits [A1-C6] at the West African Senior Secondary Certificate Examination (WASSCE) including English language and Mathematics. After online application, applicants who meet the initial requirements are shortlisted and invited to centres of their choice for further processes. At recruitment centres there is a body examination and selection as well as inspection of academic and personal documents. Successful candidates who go through body examination and selection as well as the inspection of academic and personal documents successfully are made to write an aptitude test. Candidates who pass the aptitude test go through a thorough criminal and background check, and then a medical examination for successful applicants. The final stage of the process is invitation to commence training (Ghana Police Service, Division of Human Resource, 2016).

The above is the general and standard criterion for recruiting personnel (recruits) into the Ghana Police Service. The Ghana Police Service follows these criteria religiously before a prospective applicant is recruited into the service. This means that every social institution made up of humans go by certain rules and procedures in doing things in order to create social order and fairness in the system. 


\subsubsection{Criteria for recruitment into the Ghana Police Service for Senior Officers}

The first criterion is that a prospective applicant should be Ghanaian by birth. Also, the applicant must not be more than thirty (30) years of age. The applicant must not have been dismissed from any public service or any other employment and must be at least 5 feet 8 inches $[173 \mathrm{~cm}]$ tall for males, and 5 feet 4 inches $[163 \mathrm{~cm}]$ for females. The applicants must be physically fit and must be of good character with no criminal record, be able to speak and write in fluent English language, be knowledgeable in basic computer application, have an active e-mail account and mobile phone number and be ready to undergo basic police training and other forms of training. With academic, applicants must possess a minimum of a Bachelor's Degree (at least Second Class Lower Division) in any field of study from a recognized University accredited by the Ghana National Accreditation Board and must have completed national service. After online application, applicants who meet the initial requirements are shortlisted and invited to centres of their choice for further processes. At recruitment centres there is a body examination and selection as well as inspection of academic and personal documents. Successful candidates who go through body examination and selection as well as the inspection of academic and personal documents successfully are made to write an aptitude test. Candidates who pass the aptitude test go through a thorough criminal and background check, and then a medical examination for successful applicants. The final stage of the process is invitation to commence training (Ghana Police Service, Division of Human Resource, 2016).

This process clearly confirms Parsons (1951) AGIL Taxonomy of Adaptation which is clearly illustrated in the conceptual framework of a related study by the main author titled 'Assessment of Training Practices in the Ghana Police Service'. Adaptation according to this study means securing sufficient resources from the environment and distributing these resources' throughout the system. With the theory of Adaptation, it is of the view that as trainees passes through all these processes in order to be recruited into the service it is a way in which trainees acquire the relevant knowledge pertaining to the recruitment processes in the Ghana Police Service. The above is the general and standard criterion for recruiting senior officers (graduates) into the Ghana Police Service. The Ghana Police Service follows these criteria religiously before a prospective applicant is recruited into the service to bring about social order, dynamism and progress.

3.4 Research Question 4: What are the criteria for training police officers?

Participants were asked how training is conducted in the Ghana Police Service. Participants shared common views. This is what a Trainee had to say:

"We do general cleaning which is also called fatigue, Physical Training (PT), drill, classroom work and weapon training. We also conduct parade, defensive tactics training, oral training, firearms range, scenario training, driving skills, equipment training, mental training, visiting, preps, and an examination. All these take place during the six (6) months of basic training at the various police training academies in the country".

The conceptual framework of Parsons AGIL taxonomy of Adaptation, 1951 clearly indicates the scope of training which involves library resources, classroom instructions, firearms range, scenario training rooms and the materials used in training as cited in Mensah, 2017. This clearly confirms that training in the police training schools will not be complete if the scope of training is taken out.

\subsection{Research Question 5: What is the duration for police training programme?}

With regards to the duration of the training programme, police training has certain number of periods or duration trainees' use in their training. Pokoo-Aikins (2009) said that basic police training takes six (6) months that is called the residential training. The results gathered from the study are depicted in table 4 below: Table 4: Duration of Training Programme

\begin{tabular}{lllll}
\hline Duration & Police Officers & $\begin{array}{l}\text { Winneba Trainees } \\
\text { (Senior officers) }\end{array}$ & $\begin{array}{l}\text { Accra Train. } \\
\text { (recruits) }\end{array}$ & Trainers \\
& F $(\%)$ & F $(\%)$ & F $(\%)$ & \\
\hline $5-6$ months & $10(50.0)$ & $21(63.6)$ & $62(55.9)$ & $11(55.0)$ \\
$7-8$ months & $5(25.0)$ & $4(12.1)$ & $40(36.0)$ & $7(35.0)$ \\
$9-10$ months & $5(25.0)$ & $7(21.2)$ & $9(8.1)$ & $2(10.0)$ \\
\hline
\end{tabular}


The response from the police officers shown in table 4 above revealed that $50 \%$ of the police officers used 5-6 months for police training, whereas 25\% used 7-8 months duration. With the trainees from the Winneba Police Command, 63.6\% spent 5-6 months for police training whereas $21.2 \%$ spent 9-10 months for police training. In addition, $55.9 \%$ of trainees from the National Police Training School (NPTS) spent 5-6 months whereas 36\% spent 7-8 months. With the trainers, 55\% said 5-6 months whereas $35 \%$ said 7-8 months. It can be seen from the discussion that the majority of the respondents indicated that the training takes place between 5-6 months which confirms the argument made by Pokoo-Aikins (2009).

It can also be confirmed from Reid (1996) that classroom training work spread over a period of four to six months, so that it can carefully be combined with a selected and supervised training on the field. This clearly confirms what most of the respondents said, that the training programme ranges from five (5) to six (6) months. The police institution has therefore come to accept that with this period of months, their members can effectively and efficiently be trained to tackle crime related issues and confront issues affecting the society in a more professional way.

\subsection{Motivation Factors to Pursue a Career in Law Enforcement}

Table 5 presented the motivation why most police officers pursued career in law enforcement. It is imperative to know that each police officer had a motivation factor for pursuing a career into law enforcement.

Table 5: Motivation Factors for a Career in Law Enforcement

\begin{tabular}{|c|c|c|c|c|}
\hline Variables & $\begin{array}{l}\text { Police } \\
\text { officers } \\
\text { F }(\%)\end{array}$ & $\begin{array}{l}\text { Winneba } \\
\text { Trainees } \\
\text { (Senior } \\
\text { officers) } \\
\mathrm{F}(\%)\end{array}$ & $\begin{array}{l}\text { Accra Trainees } \\
\text { (recruits) }\end{array}$ & Trainers \\
\hline $\begin{array}{l}\text { Opportunity to help- } \\
\text { people in the } \\
\text { community }\end{array}$ & $6(30.0)$ & $5(15.1)$ & $8(7.2)$ & $2(10.0)$ \\
\hline Job security & $5(25.0)$ & $5(15.1)$ & $19(17.1)$ & $2(10.0)$ \\
\hline $\begin{array}{l}\text { Prestige and status of- } \\
\text { the occupation }\end{array}$ & $2(10.0)$ & $2(6.1)$ & $2(1.8)$ & $1(5.0)$ \\
\hline Authority and Power & $3(15.0)$ & $1(3.0)$ & $2(1.8)$ & $1(5.0)$ \\
\hline To fight crime & $2(10.0)$ & $1(3.0)$ & $3(2.7)$ & $1(5.0)$ \\
\hline The salary and other- & $2(10.0)$ & $19(57.6)$ & $77(69.4)$ & $13(65.0)$ \\
\hline
\end{tabular}

benefits

It became evident from the study that $30 \%$ of police officers were revealed to have joined the police service mainly because of the opportunity to help people in the community. Furthermore, $25 \%$ of the police officers were of the view that job security is their motivation factor for being in the police service, whereas $15 \%$ on the average confirmed that their motivation factor was authority and power.

Data gathered from the study also revealed that $57.6 \%$ of the trainees from the Winneba Police Training School confirmed that their motivation factor for being in the police service was the salary and other benefits, $15.1 \%$ also said that opportunity to help people in their community and job security was their prime motivation factor for being in the police service.

On the other hand, $69.4 \%$ trainees from the NPTS also claimed that salary and other benefits was the major factor for being in the police service. Conversely, $17.1 \%$ also indicated that job security was their motivation factor whereas $7.2 \%$ of these trainees claimed that they had a dire interest of helping people in the community.

It also came to light that, $65 \%$ of trainers were of the view that salary and other benefits was their motivation factor for being in the police service, whereas $10 \%$ each claimed that they entered in the police service with the sole aim of helping people in the community and for job security purposes respectively. It can be concluded that majority of the respondents were of the view that the motivation factor for entering into the police service was because of the salary and other benefits as the major factor and getting the opportunity to help people in their community. Its sociological implication is that police officers are in dire need to satisfy their 
physiological needs such as food, drink, shelter, warmth and other basic needs, therefore they are more intrigued in their salary than any other thing. Lastly of these motivating factors is their quest to help people in the community as part of the core mandates of the police. In helping and protecting people from harm and fear, they are satisfying the basic needs of citizens in line with the core mandate of the police to protect lives and properties and to provide education to the community about their personal security needs.

\subsection{Conclusions}

4.1 Socioeconomic Characteristics of Trainees, Trainers and Police Officers

The background information about the various respondents in this study was relevant to this study because the socioeconomic context in which respondents found themselves influenced their reactions. The findings of this research have shown that most trainees interviewed were males than females. This implies that males are more than females in the Ghana Police Service.

In addition, the study revealed that the Akans dominated the Ghana Police. This gives a clear implication that Akans are mostly recruited during police recruitment processes or are given the utmost priority in police recruitment process. Notwithstanding, most of these police trainees were unmarried. This also means that the police service rigorously follows certain standards and principles before recruits get married unlike the senior officers. It was also revealed that most of the respondents in the police service were motivated by the amount of money they expect to receive as salaries. This implies that personnel in the police service have their salaries as their topmost priority before any other thing follows.

\subsection{Qualification (s) of respondents}

The study further revealed that majority of the respondents were Senior High School Certificate holders and they did not have any relatives as police officers before they entered into police service. This implies that Senior High School graduates are employed more than any other category in the Ghana Police Service.

\subsection{Criteria for recruitment}

The study revealed that the police service has a general and standard criterion for recruiting personnel (recruits) into the Ghana Police Service. The Ghana Police Service follows these criteria religiously before a prospective applicant is recruited into the service (see research question 3 above under results and discussion for criteria)

\subsection{Criteria for Training}

It is concluded that the criteria for police training takes the form of Physical Training (PT), drill, classroom work, weapon training, parade, defensive tactics training, oral training, firearms range, scenario training, driving skills, equipment training, mental training, visiting, preps, and an examination.

\subsection{Duration for the Training Programme}

Also, it was observed that most of the respondents took within 5-6 months to complete their training programme with a good student-lecturer relationship at the training academies.

\subsection{Motivational factors for one to pursue career in law enforcement}

It can be concluded that majority of the respondents were of the view that the motivation factor for entering into the police service was because of the salary and other benefits as the major factor and getting the opportunity to help people in their community.

\subsection{Recommendations}

1. The government, in collaboration with the Ghana Police administration, and the Ministry of Interior must improve upon the level of motivation and salary packages of the police service to make it more interesting and attractive to the youth which will in turn keep them in the police force to help maintain law and order in the country.

2. The government, through the Ministry of Interior, must encourage and motivate the authorities in the various police training institutions as well as the police service in general for the professional ways in which they apply their training skills in maintaining law and order in the country.

3. The government and the other stakeholders, through parliament, must help to enact a law or device a code of conduct that will reduce or eliminate political interference during recruits' selection period. This will help produce quality and deserving graduates from the police service who will deliver expectably.

\section{References}

Castillo, J. J. (2009). Population sampling techniques. Retrieved on September, 9, 2010.

Cox, S. M. (1996). Police: Practices, perspectives, problems. Allyn and Bacon Boston.

Retrieved from https://www.ncjrs.gov/App/abstractdb /AbstractDBDetails.aspx?id=162707 
Dantzker, G., Lurigio, A. J., Hartnett, S., \& Houmes, S. (1995). Preparing police officers for community policing: An evaluation of training for Chicago's alternative policing strategy. Police Studies International Review Police Development 18, 45.

Ghana Police College, Course syllabus, revised (2009).

Ghana Police Service, Division of Human Resource. (2016). Ghana Police Service, Division of Human Resource Reports.

Ghana Statistical Service (2010). Population and housing census final report. Ghana: Accra.

Kumekpor, T. K. (2002). Research methods and techniques of social research. SonLife Press \& Services.

Mensah, R. O. (2019). Social outcomes of training practices in the Ghana Police Service. Research on Humanities and Social Sciences, 9, 69-82.

Mensah, R. O. (2018). Assessment of training practices in the Ghana Police Service. Journal of Law, Policy and Globalization, 79, 265-273.

Mensah, R. O. (2017). Assessment of training Practices in the Ghana Police Service. master's thesis. University of Cape Coast, Cape Coast, Ghana

Ogula, P.A. (2005). Research methods. Nairobi: Catholic University of Eastern Africa Publications.

Parsons, T. (1951). Social structure and dynamic process: the case of modern medical practice. Retrieved from https://repository.library.george town.edu/handle/10822/762066

Pokoo-Aikins, J. B. (2009). The police in Ghana, 1939-1999. Pokoo-Aikins.

Taale, L. ,\& Ngman-Wara, Y. (2015). Social research methods. Retrieved from https://opentext.wsu.edu/carriecuttler/chapter/reliability-and-validity-of-measurement

Trojanowicz, R. C., \& Belknap, J. (1986). Community policing: Training issues. National Neighborhood Foot Patrol Center, School of Criminal Justice, Michigan State University. Retrieved from http://msucj. bcpdev.com/assets/Outreach-NCCP-GB9.pdf

Webster, R. (1985). Quantitative spatial analysis of soil in the field. In Advances in soil science (pp. 1-70). Springer. Retrieved from http://link.springer.com/chapter/10.1007/978-1-4612 5090-6_1 